\title{
Editorial \\ Spatial Modelling in Environmental Analysis and Civil Engineering
}

\author{
Artur Janowski ${ }^{1,2} \mathbb{D}$, Jakub Szulwic ${ }^{2}$ and Paweł Tysiąc ${ }^{2, *(\mathbb{D})}$ \\ 1 Institute of Geodesy, Faculty of Geodesy, Geospatial and Civil Engineering, University of Warmia and \\ Mazury in Olsztyn, 10-719 Olsztyn, Poland; artur.janowski@geodezja.pl \\ 2 Department of Geodesy, Faculty of Civil and Environmental Engineering, Gdansk University of Technology, \\ 80-233 Gdańsk, Poland; szulwic@pg.edu.pl \\ * Correspondence: pawtysia@pg.edu.pl
}

check for updates

Citation: Janowski, A.; Szulwic, J.; Tysiąc, P. Spatial Modelling in Environmental Analysis and Civil Engineering. Appl. Sci. 2021, 11, 3945. https://doi.org/10.3390/ app11093945

Received: 16 April 2021

Accepted: 22 April 2021

Published: 27 April 2021

Publisher's Note: MDPI stays neutral with regard to jurisdictional claims in published maps and institutional affiliations.

Copyright: (c) 2021 by the authors. Licensee MDPI, Basel, Switzerland. This article is an open access article distributed under the terms and conditions of the Creative Commons Attribution (CC BY) license (https:/ / creativecommons.org/licenses/by/ $4.0 /)$.

\section{Spatial Modelling in Environmental Analysis and Civil Engineering}

Nowadays, practicing research on the principles of sustainable development is very important. This allows to counteract the negative effects of anthropopression and adverse environmental phenomena that reduce the quality of life. This confirms the need to develop new methods to help us understand the processes that surround us. One example of such processes appeared in the special issue via remote sensing identification of wind erosion [1]. Agricultural land affected by wind erosion is characterized by a reduced soil quality, which consequently leads to economic losses. Therefore, the application of the method may be used in the development and implementation of programs aimed at mitigating the effects of wind erosion. One of the advantages of the publication is the multitude of databases used, showing possible multidisciplinary activities.

An important subject, described in the special issue was the development of manmade infrastructure in relation to the processes of the natural environment taking place in the vicinity of this infrastructure. Ghafari et al. [2] shows the problem related to the development of transport. Its expansion is very important due to the constantly growing number of people using it. The research on a spatial model in the form of a tunnel was presented and it was found that in addition to the construction design of the tunnel, the geotechnical design also has a large impact on safety and strength. Particular aspects such as soil properties, tunnel depth and step angle have a strong influence on structural damage. It has been shown that this has not been taken into account in previous studies. In connection with the above (taking into account possible seismic events), a design method was presented that increases the safety of newly created metro lines, taking into account possible obstacles that could cause a catastrophe.

A very interesting issue raised in [3] is the use of Building Information Modelling (BIM) in engineering activities. The authors point out that most of references present successful case studies using common building construction methods and technologies, but rarely touch upon real implementation problems. The authors show that in the case of BIM methodology in the field of transport infrastructure, construction activity is only a part of infrastructure's life. Additionally, works related to the expansion, renovation and maintenance of infrastructure should be taken into account. The relevance of this research is based on an original view of BIM in civil engineering applications through four case studies. Two of them focused on design options and two on exploitation, rehabilitation and maintenance options. The results showed that, despite the lack of previous experience, the use of BIM methodology is possible for activities such as maintenance, management or infrastructure expansion using various specific software packages. In view of the above, it seems reasonable to develop practical measurement solutions in order to determine the correct course of the railway track line. Koc et al. [4], showed the methodology of axle measurement, but also described the method of determining corrections to achieve better results. 
When analysing the method of obtaining information about buildings (BIM), we need to focus on risk management during construction works [5]. The problem is the overall assessment of the risk of a disaster. Therefore, a very interesting and practical solution by Lee et al. [5], shows a solution to this problem by deriving a BIM-based risk assessment scenario.

From the risk assessment, safety and measurement methods in the Special Issue, attention was paid to the execution technology in construction. As is commonly known, the first step is to design or inventory the structure to be modernized. An interesting aspect to optimize these processes was discussed in [6]. The article has developed an algorithm for finding the minimum set of axial lines that can represent the geometry of a building and an urban layout in two dimensions. Apart from the geometry itself, the problem of discrete elements is also discussed. Nan et al. [7] discusses the solutions for topology optimization of spatially discrete structures. In this way, the topic of optimization of processes related to the geometry of the structure and engineering calculations was raised.

When considering practical solutions in the field of spatial modelling, it is worth discussing examples related to the real case studies. As an example, the problem described in the special issue is a numerical simulation of a turbulent wind field on long-span bridges. $\mathrm{Xu}$ et al. [8] optimized the spectral representation method and the obtained results show that the updated method works well in generating a non-stationary turbulent wind field. The obtained wind fields will serve as the research basis for the analysis of non-stationary shock behaviour and other wind-sensitive structures. When using specific solutions, it is worth mentioning the work [9], in which researchers proposed a resistance system to be used in deep excavations in crowded cities. Thanks to the comparisons, the authors showed that the obtained results indicate that the application of the system significantly reduces the deformation of vertical piles and the bending moments acting on them.

Showing and realizing the complexity of the subject offered in Special Issue, practical methods of modelling structural elements or the natural environment have emerged. The publication [10] focused on determining the geometrical parameters of the rotary kiln in a non-traditional geodetic manner-based on measurements carried out by a terrestrial laser scanner (TLS). The solution significantly optimizes and accelerates the inventory work. On the other hand, the publication [11] focused on research aimed at reducing the risk of low-altitude unstable approach (UA) events. The modelling found correlations between the AU and altitude, wind level and bad weather, and the correlation differences were also reflected in different regions of China.

\section{Future Advances in Spatial Modelling in Environmental Analysis and Civil Engineering}

As can be seen, Spatial Modelling in Environmental Analysis and Civil Engineering applies to a multitude of applications. In an attempt to bring the topic closer to potential readers, the special issue referred to security methods, optimization of calculations, conducting measurements and empirical tests. Each article has made an original contribution to the development of practical science that can be replicated by researchers around the world. Being aware of the multitude of technological solutions and possible applications, we want to promote this type of research.

Conflicts of Interest: The authors declare no conflict of interest.

\section{References}

1. Baumgertel, A.; Lukić, S.; Simić, S.B.; Kadović, R. Identifying Areas Sensitive to Wind Erosion-A Case Study of the AP Vojvodina (Serbia). Appl. Sci. 2019, 9, 5106. [CrossRef]

2. Ghafari, M.; Nahazanan, H.; Yusoff, Z.M.; Daud, N.N.N. A Novel Experimental Study on the Effects of Soil and Faults' Properties on Tunnels Induced by Normal and Reverse Faults. Appl. Sci. 2020, 10, 3969. [CrossRef]

3. Bazán, Á.M.M.; Alberti, M.G.; Álvarez, A.A.A.; Trigueros, J.A. New Perspectives for BIM Usage in Transportation Infrastructure Projects. Appl. Sci. 2020, 10, 7072. [CrossRef] 
4. Koc, W.; Specht, C.; Szmaglinski, J.; Chrostowski, P. A Method for Determination and Compensation of a Cant Influence in a Track Centerline Identification Using GNSS Methods and Inertial Measurement. Appl. Sci. 2019, 9, 4347. [CrossRef]

5. Lee, Y.; Kim, I.; Choi, J. Development of BIM-Based Risk Rating Estimation Automation and a Design-for-Safety Review System. Appl. Sci. 2020, 10, 3902. [CrossRef]

6. Jung, S.K.; Kim, Y. A Linear Programming Method for Finding a Minimal Set of Axial Lines Representing an Entire Geometry of Building and Urban Layout. Appl. Sci. 2020, 10, 4273. [CrossRef]

7. Nan, B.; Bai, Y.; Wu, Y. Multi-Objective Optimization of Spatially Truss Structures Based on Node Movement. Appl. Sci. 2020, 10, 1964. [CrossRef]

8. Xu, Z.; Wang, H.; Zhang, H.; Zhao, K.; Gao, H.; Zhu, Q. Non-Stationary Turbulent Wind Field Simulation of Long-Span Bridges Using the Updated Non-Negative Matrix Factorization-Based Spectral Representation Method. Appl. Sci. 2019, 9, 5506. [CrossRef]

9. Zhang, Y.; Chen, C.; Lei, M.; Zheng, Y.; Zhang, H.; Shao, Y. Preliminary Numerical Analysis of a Novel Retaining System in Dry Sandy Soil and Its First Application to a Deep Excavation in Wuhan (China). Appl. Sci. 2020, 10, 2006. [CrossRef]

10. Kovanič, L'.; Blistan, P.; Urban, R.; Štroner, M.; Pukanská, K.; Bartoš, K.; Palková, J. Analytical Determination of Geometric Parameters of the Rotary Kiln by Novel Approach of TLS Point Cloud Segmentation. Appl. Sci. 2020, 10, 7652. [CrossRef]

11. Sun, H.; Xie, J.; Jiao, Y.; Huang, R.; Lu, B. Event Detection and Spatio-temporal Analysis of Low-Altitude Unstable Approach. Appl. Sci. 2020, 10, 4934. [CrossRef] 